\title{
Genetic Variation of Bread Wheat (Triticum aestivum $L$.) Varieties Based on Phenological, Morphological and Quality Traits at Guay Kebele in Debre Elias District, East Gojjam Zone, Northwestern Ethiopia
}

\author{
Habtamu Kefale* Ahadu Menzir (PhD) \\ Debre Markos University, College of Agriculture and Natural Resource, Department of Plant Science, Ethiopia
}

\begin{abstract}
Genetic variation study was conducted at Guay Kebele, D/Elias district in 2018/19, to select superior varieties of bread wheat on farmer's field. Ten alternative bread wheat varieties including standard check were evaluated under rain fed conditions using a randomized complete block design with three replications. The analysis of variance (ANOVA) of phenological, agronomic and quality traits indicated the presence of significant $(\mathrm{P}<0.05)$ variation in protein content and harvest index while, days to $50 \%$ emergence, days to $75 \%$ heading, days to maturity, plant height, effective tiller, spikelet per spike, spike length, grain per spike, biomass yield, grain yield, 1000 kernel weight, hectoliter weight showed highly significant $(\mathrm{P}<0.01)$ difference. Abola $\left(3.99\right.$ ton-ha $\left.^{-1}\right)$ and Ogoloncho $\left(3.87\right.$ ton-ha $\left.^{-1}\right)$ were the higher yielders over the standard check $\left(\right.$ Kekeba $=3.18$ ton-ha $\left.{ }^{-1}\right)$ and to the other varieties tested. Grain yield revealed strong, positive and highly significant correlation with harvest index $\left(\mathrm{r}=0.88^{* *}\right)$, plant height $\left(\mathrm{r}=0.67^{* *}\right)$, number of effective tillers $\left(\mathrm{r}=0.73^{* *}\right)$, spike length $\left(\mathrm{r}=0.74^{* *}\right)$, spikelet per spike $\left(\mathrm{r}=0.70^{* *}\right)$, number of grain per spike $\left(\mathrm{r}=0.80^{* *}\right)$, biomass yield $\left(\mathrm{r}=0.85^{* *}\right), 1000$ seed weight $\left(\mathrm{r}=0.76^{* *}\right)$ and hectoliter weight $\left(\mathrm{r}=0.83^{* *}\right)$. The higher genotypic coefficient of variation was observed from thousand kernel weight $(79.27 \%)$ and the higher phenotypic coefficient of variance was also observed from thousand kernel weight (88.25) and effective tiler weight (26.94\%). Spikelet per spike (92.42\%), grain yield (80.39\%), hectoliter weight $(96.6 \%)$, plant height $(85.49 \%)$ and days to physiological maturity $(95.7 \%)$ had higher heritability with moderate and low genetic advances. Therefore, based on the results of this there were variability among the tested varieties and then Abola and Ogoloncho are recommended for any genetic improvement as well as for production in the study area.
\end{abstract}

Keywords: Bread wheat, coefficient of variation, correlation, heritability, standard check

DOI: $10.7176 / \mathrm{JBAH} / 9-11-07$

Publication date:June $30^{\text {th }} 2019$

\section{INTRODUCTION}

Bead wheat (Triticum aestivum $\mathrm{L}$. $2 \mathrm{n}=6 \mathrm{x}=42$ ), is alloploid, a self-pollinating annual plant in the true grass family Gramineae (Poaceae) and it is largest cereal crop extensively grown as staple food sources in the world (Mollasadeghi et al., 2012). Wheat provides more nourishment for the people of the world than any other crop, and provides the nutrition for the greater part of the world population. The world wheat production is 728.3 million tons and East Africa produced 5.7 million tons, from this Ethiopia had a share of 4.6 million tons (FAO, 2019).

Wheat is grown at an altitude ranging from 1500 to 3000 meters above sea level, between 6-160 N latitude and 35-420 E longitude but its suitable agro- ecological zones, fall between 1900 and $2700 \mathrm{~m}$ a.s.l. (Kifle et al., 2016). Wheat is the third most important small cereal crops in Ethiopia in terms of cultivated land, food value and number of smallholders engaged in production after Tef (Eragrostis tef L.) and Maize (Zea mays L.) (Birhanu et al., 2016).

The total wheat area coverage and production in the Amhara region was $554,661.74$ ha $(32.7 \%$ of the countries coverage) and 1319197.1 tons respectively with the productivity of 25.33qt/ha in 2016/17 Meher season (CSA, 2017). In Amhara region administrative Zones, East Gojjam zone Ranks first in area coverage and productivity which is $127,469.49$ ha with $25.05 \mathrm{qt} / \mathrm{ha}$ followed by South Wollo $99,702.51$ ha with $22.98 \mathrm{qt} / \mathrm{ha}$, and North Shoa $83,238.27$ ha with $25.96 \mathrm{qt} / \mathrm{ha}$ respectively (CSA, 2017). The productivity of wheat in this administrative zone $(25.09 \mathrm{qt} / \mathrm{ha})$ is relatively better than regional productivity $(23.80 \mathrm{qt} / \mathrm{ha})$ but, lower than the national average (26.75qt/ha) (CSA, 2017).

However, wheat production is limited with disease, low productivity, limited availability of varieties especially using of old improved and sole variety Kekeba in the study area. Hence, to make an effective selection for grain yield, understanding the genetic variability, heritability and genetic advance as percent of mean as well as the association of grain yield with yield contributing characters is important (Birhanu et al., 2016). According to Abhilasha et al. (2018), the availability of a wide variability provides the breeder with a greater chance of selecting desired material. In addition, to evolve superior genotype for further hybridization and selection it is important to get precise information on the nature and degree of genetic diversity present in wheat collections from principal areas of cultivation. Existence of genetic diversity is very essential to meet the present and future crop breeding challenges. It is a prerequisite for the development of improved cultivars with wider adaptability and 
broad genetic base (Hailu, 2011).

Therefore, genetic variation of bread wheat varieties based on phenological, growth and quality traits selection was conducted to evaluate and identify high yielding and good quality of bread wheat based on the difference in the genetic makeup of the varieties at Guay Kebele in Debre Elias district.

\section{MATERIALS AND METHODS}

\subsection{Description of Experimental site}

Genetic variation of bread wheat trial was conducted at Guay Kebele in Debre Elias district, East Gojjam Zone in 2018/2019 main cropping season. The study area (Debre Elias) is located around $335 \mathrm{~km}$ northwest from Addis Ababa and $42 \mathrm{kms}$ from Debre Markos city. Debre Elias is one of the districts of Amhara region in E/Gojjam Zone. It is bordered on the south and west by Abay river which separates it from Oromia region, on the northwest by west Gojjam zone, on the north by Machakel district and on the east by Gozamin district. The district town is called Elias. The mean annual temperature of the district ranges from $18-27^{\circ} \mathrm{C}$ and receives mean annual rainfall of $1150 \mathrm{~mm}$ and red soils are the dominant soil type and it is moderately fertile (Achenef and Admas, 2012). The district comprises altitudes ranging between 800 and 2600 m.a.s.l and about $99 \%$ of the district is mid altitude. The area mainly consists of plain topography $(85 \%)$ while the rest $(15 \%)$ is undulating topography. Debre Elias has an area of about 94,000 ha and its population size is 102,000 . The average land holding of the district is 1.93 ha per household and its average family size is six. The most important crops grown in the district are Wheat, Tef, Maize, Faba bean, Barley, Niger seed and linseed (Debre-Elias District Agriculture and Rural Development Office, 2005). In this area, agriculture is predominantly rain fed.

\section{a. Experimental materials}

The experimental materials used for the study include Tsehay, Shorima, Danda'a, Wane, Ogoloncho, Kekeba, King bird, Lemu, Tay and Abola Bread wheat varieties Those varieties were developed by different research institutes. They have chosen based on superiority in grain yield performance (high yielding), disease resistance, stability and wide adaptation.

Table 1. List of Varieties tested at Guay and Tijagotir in 2018/2019.

\begin{tabular}{|c|c|c|c|c|c|c|}
\hline \multirow{2}{*}{$\begin{array}{l}\text { Treatment } \\
\text { no }\end{array}$} & \multirow[b]{2}{*}{ Variety Name } & \multirow{2}{*}{$\begin{array}{l}\text { Source/ } \\
\text { Releaser }\end{array}$} & \multirow{2}{*}{$\begin{array}{l}\text { Year of } \\
\text { Release }\end{array}$} & \multicolumn{2}{|c|}{ Adaptation Zone } & \multirow{2}{*}{$\begin{array}{l}\text { Productivity } \\
\text { (Q/ha) }\end{array}$} \\
\hline & & & & $\begin{array}{l}\text { Altitude } \\
\text { (M a.s.l ) }\end{array}$ & $\begin{array}{l}\text { Rain fall } \\
\text { (mm) }\end{array}$ & \\
\hline 1 & Ogoloncho & Kulmsa & 2012 & $1600-2100$ & $400-500$ & $33-50$ \\
\hline 2 & Tsehay (HAR-3837) & Kulmsa & 2014 & $2600-3100$ & $>900$ & 38 \\
\hline 3. & Shorima(ETBW5483) & Kulmsa & 2011 & $1900-2600$ & $600-900$ & $44-63$ \\
\hline 4. & Kekeba & Kulmsa & 2010 & $1500-2000$ & $500-800$ & $33-52$ \\
\hline 5. & Danda'a & Kulmsa & 2010 & $2000-2600$ & $>600$ & $35-55$ \\
\hline 6. & Tay & Adet & 2005 & $1900-2800$ & $>700$ & $25-61$ \\
\hline 7. & King Bird & Kulmsa & 2015 & $1500-2200$ & $500-850$ & $46.5-63.1$ \\
\hline 8 & Lemu & Kulumsa & 2016 & $>2200$ & $800-1100$ & $55-65$ \\
\hline 9 & Wane & Sinana & 2016 & $2100-2700$ & $700-1000$ & $50-60$ \\
\hline 10 & Abola(HAR-1522) & $\begin{array}{l}\text { D/Birhan } \\
\text { ARC }\end{array}$ & 1997 & $2200-2700$ & $>600$ & $40-65$ \\
\hline
\end{tabular}

\subsection{Experimental Design and Trial Management}

The mother trial experiment was laid out by RCBD with three replications in Guay FTC having full set up while the baby trial was also laid out in RCBD method with locations/sites as replications. The varieties were randomized in each field and each of them was planted on the plot of $7.5 \mathrm{~m}^{2}(2.5 \mathrm{mx} 3 \mathrm{~m})$ having $1 \mathrm{~m}$ and $0.5 \mathrm{~m}$ spacing between blocks and plots respectively. During sowing, the seeds were manually drilled into three meters long in 10 rows and plots were spaced $25 \mathrm{~cm}$ apart.

\subsection{Data Collected}

Data collected on plant basis was (plant height, spike length, spikelet per spike, fertile tiller per plant kernels per spike, yellow rust, leaf rust and stem rust) and plot basis (days to 50\% emergence, days to heading, days to $90 \%$ maturity, above ground biomass, grain yield, harvest index, hectoliter weight and protein content). For data collection on plant bases, ten plants were randomly taken from the six middle rows of each plot excluding the four rows from both sides of each plot which were considered as border and the mean value of these ten plants was calculated using Micro soft Excel and used as plot data for analysis. Yield data was also taken from the plot net area which was $\left(3 \mathrm{~m}^{2}\right)$ and then, converted to ton-ha ${ }^{-1}$. The study data were recorded on the phenological, growth, yield and yield related trait and quality traits. 


\subsection{Statistical Analysis}

\section{(i) Analysis of Variance (ANOVA)}

The data collected for each quantitative trait subjected to Proc GLM procedures of SAS software version 9.4 (SAS, 2013) with treatment and replications as the class variables and the response variables were the traits on which data was collected.

(ii) Analysis of genetic parameters/ Variance components

\section{a. Estimation of phenotypic and genotypic coefficient of variance}

The genotypic and phenotypic variance components and coefficient of phenotypic and genotypic variability were estimated according to the method suggested by Burton and Devane (1953)

$\checkmark$ Genotypic coefficient of variability $(\mathrm{GCV})=\underline{\sqrt{\sigma 2 \mathrm{~g} \times 100}}$

$\checkmark \quad$ Phenotypic coefficient of variability $(\mathrm{PCV})=\sqrt{\sigma 2 \mathrm{p}} \times 100$

$\mathrm{X}$

$\checkmark$ Environmental coefficient of variation $(\mathrm{ECV})=\frac{\sqrt{\sigma 2 \mathrm{e}} \times 100}{\mathrm{X}}$

\section{$\mathrm{X}$}

Where $\sigma 2 \mathrm{~g}=$ Genotypic variance, $\sigma 2 \mathrm{p}=$ phenotypic variance, $\sigma 2 \mathrm{e}=$ environmental variation and $\mathrm{x}=\mathrm{Grand}$ mean of a character. Genetic improvement of any character is difficult without having sufficient genetic variability. Therefore, the existence of genetic variability in population is pre-requisite for any crop improvement programme. Fisher (1918) interprets quantitative characters in terms of Mendelian genetics and subsequently the estimates of genotypic and phenotypic variations were used to predict the expected genetic response. The coefficient of variability is used to assess the extent of variability between two diverse characteristics. The variance component is used to compute the genotypic coefficient of variability (GCV), phenotypic coefficient of variability (PCV) and expected genetic advance.

\section{b. Estimation of heritability in broad sense and Genetic advance}

Heritability is difference due to the environment and inheritance. The greater the proportion of the total variability that is due to the environment, the more difficult it would be to select for inherent differences. On the other hand, if environmental variability is small in relation to genotypic differences, selection will be efficient, because the selected character will be transmitted to the progeny. The inherent portion of the variability is termed as heritability (Allard, 1960). Heritability $(\mathrm{H})$ : heritability in broad sense for all characters was computed using the formula given by Falconer, (1997) and Hanson et al., (1956).

Heritability $\left(\mathrm{h}^{2} \mathrm{~b}\right)=\underline{\sigma^{2}} g \times 100$

Where: $\mathrm{H}=$ heritability in broad sense,$\sigma^{2} p=$ Phenotypic variance, $\sigma^{2} g=$ Genotypic variance.

The broad sense heritability estimates were classified as low, moderate and high as follows: $0-40 \%=$ Low, 40 $80 \%=$ Moderate, and $>80 \%=$ High (Singh et al., 2001).

\section{c. Genetic advance expected}

Genetic advance is also considerable importance because it indicates the magnitude of the expected genetic gain from one cycle of selection (Hamdi et al., 2003). High genetic advance coupled with high heritability estimates offers the most effective condition for selection (Larik et al., 2000). Heritability measures the degree to which the variability of a character is transmitted to the progeny, serves as a guide to the reliability of phenotypic variability in the selection programme and hence determines its success (Dawit et al., 2012). However, Johnson et al. (1955) stated that heritability estimates together with genetic advance are more important than heritability alone to predict the resulting effect of selecting the best individuals. Genetic advance was computed using the formula suggested by Allard (1960) and Johnson et al., (1955). GA $=(\mathrm{k})(\sigma \mathrm{p})(\mathrm{h} 2)$ or $(\mathrm{k}) .(\sqrt{\mathrm{P} v}) .\left(\mathrm{h}^{2} \mathrm{~b}\right)$. Where, $\mathrm{k}=$ selection differential (at $5 \%$ selection intensity $=2.06), \sigma \mathrm{P}=$ phenotypic standard deviation $(\sqrt{\mathrm{Pv}}=$ expressed the phenotypic standard deviation), $\mathrm{h}^{2} \mathrm{~b}=$ broad sense heritability. The GA was categorized as, $<10 \%=$ Low, $10-20 \%=$ Moderate, and, $>20 \%=$ High

\section{RESULT AND DISCUSSION}

\subsection{Analysis of Variance (ANOVA)}

Mean squares of the 14 characters from analysis of variance (ANOVA) are presented in (Table 2). Highly significant differences among varieties $(\mathrm{P}<0.01)$ were observed for Twelve characters (days to emergence, days to heading, days to maturity, plant height, effective tillers per plant, spike length, spikelets per spike, grain per spike, 1000 kernel weight, biomass yield, grain yield and hectoliter weight), significant at $(\mathrm{p}<0.05)$ for the rest two characters; namely, harvest index and protein content. This result indicating that there is variability among the genotypes studied and would respond positively to selection. 
Table 2. Analysis of variance (ANOVA) for the 14 characters of 10 bread wheat varieties grown at Guay (2018/19)

\begin{tabular}{lllll}
\hline Traits & MSt & MSr & Mse & CV(\%) \\
\hline DE & $3.05^{* *}$ & $0.90^{*}$ & 0.19 & 6.15 \\
DH & $60.40^{* *}$ & $12.70^{*}$ & 2.95 & 2.57 \\
DM & $213.41^{* *}$ & 3.90 & 3.12 & 1.61 \\
PH & $172.35^{* *}$ & 10.13 & 9.23 & 3.60 \\
ETL & $1.53^{* *}$ & 0.18 & 0.60 & 7.46 \\
SPL & $2.37^{* *}$ & $0.54^{*}$ & 0.11 & 4.47 \\
SPS & $5.66^{* *}$ & $3.60^{* *}$ & 0.15 & 2.27 \\
NGS & $110.81^{* *}$ & $140.40^{* *}$ & 13.36 & 7.76 \\
BY & $4.00^{* *}$ & 1.87 & 0.65 & 8.40 \\
GY & $1.35^{* *}$ & 0.19 & 0.12 & 12.11 \\
TKW & $16.44^{* *}$ & $3.79^{*}$ & 1.01 & 2.81 \\
HI & $38.82^{*}$ & 4.59 & 10.88 & 11.17 \\
HLW & $25.08^{* *}$ & $6.84^{* *}$ & 0.29 & 1.79 \\
PC & $0.99^{*}$ & $8.71^{*}$ & 0.71 & 6.49 \\
\hline
\end{tabular}

Where, $M S t=$ mean squire due to treatments, $M S r=$ mean squire due to replication, $M S e=$ mean squire due to error, $C V=$ coefficient of variation, $n s=$ non-significant, $D E=$ days to $50 \%$ emergence, $D H=$ days to $75 \%$ flowering, $D M=$, days to $90 \%$ maturity, $P H=$ plant height, ETN= effective tiller number, SPS = spikelet per spike, $S P L=$ spike length, $*=$ significant, $* *=$ highly significant, $N G S=$ number of grains per spike, $B Y=$ biomass yield, $T K W=$ thousand kernel weight, $H I=$ harvest index in \%, HLW= hectoliter weight, $P C=$ protein content.

\subsection{Comparison of bread wheat varieties in phenological, growth and quality traits}

The analysis of variance (ANOVA) of phenological, growth and quality traits revealed the presence of highly significant variance $(\mathrm{P}<0.01)$ among the tested varieties for 12 characters studied while significant variance $(\mathrm{P}<0.05)$ for harvest index and protein content (Table 2). In contrast to the present study, non-significant difference was observed among the varieties for, spike length, number of fertile tillers per plant, number of spikelet per spike and number of kernels per spike (Obsa et al., 2018). Mean values for phenological, growth and quality traits are presented in mean separation table (Table 3 ).

\section{a. Phenological traits:}

Days to 50\% emergence; Variety Kekeba (5.66 days), Tsehay (6.33 days), Wane (6.33 days) and Kingbird (7.33 days) emerged earlier than other varieties while Abola (8.33 days) and Tay (8.00 days) were emerged lately than the rest tested varieties. The variations of varieties in days to $50 \%$ emergence indicate that the existence of variation in genetic makeup. This could be used in the selection program due to its direct effect on days to heading and maturity. In areas where rainfall scarcity and fluctuation, early maturing varieties might have vital role in escaping the season of moisture stress.

Days to $75 \%$ heading: With respect to days to $75 \%$ heading, shortest day to heading was recorded for variety Kekeba (58 days) and longest day to heading was revealed by variety Lemu ( 75 days). This indicates that from the tested varieties Kekeba took short period of time to reach heading stage whereas Abola, Lemu, Tay and Danda'a took prolonged period of time. This result agrees with the findings of (Kifle et al., 2017) who reported that there was highly significant variation among the tested varieties. This also in line with Assaye et al. (2013) who reported significant difference among the tested varieties at Wonberma district.

Days to $90 \%$ physiological maturity: Kekeba was early maturing variety ( 92 days) followed by Shorima (98 days) whereas, Abola, Tay, and Ogoloncho was late maturing varieties with 118, 116 and 115.66 days respectively (Table 4.6). Likewise, Astawus Esatu, (2016) reported that verities Kekeba (58.7 days) and Kingbird (61 days) headed early and Kekeba (105 days) was matured early than Kingbird. This could be the fact that early matured varieties require shorter period to reach physiological maturity and lately headed varieties also require longer period to mature. Kifle et al. (2017) reported comparative result of 112.67 days to maturity for variety Mekele 01 and 109 days to maturity for variety Mekele 02.

b. Growth and agronomic traits:

Plant height; Abola (94.54 cm), Tay (94.50) and Danda'a $(89.83 \mathrm{~cm})$ were the tallest varieties while Wane $(71.88$ $\mathrm{cm})$ and Lemu $(76.37 \mathrm{~cm}$ ) was the shortest varieties (Table 3). Astawus Esatu, (2016) reported that TAY (102.9 $\mathrm{cm})$ and Danda'a $(98.6 \mathrm{~cm})$ had the highest plant height while Kingbird $(77.9 \mathrm{~cm})$ and Kekeba $(80.3 \mathrm{~cm})$ were the shortest varieties. The varieties which had the highest plant height in both trials resulted higher above ground biomass and grain yield. This might be due to the direct effect of plant height i.e. when plant height increases, spike length, number of grain per spike and spikelets per spike could increase and as result it may have attributed to increase in biomass and grain yield. Significant variation among bread wheat genotypes for plant height was also reported by many authors including by (Assaye et al., 2013, Asefa et al., 2014, Obsa and Yared, 2017). In contrast, non-significant variation in plant height among bread wheat varieties was reported by Fano and Tadeos, 
(2017).

Effective tillers per plant: The number of effective tiller per plant ranged from 2.68 to 4.86 as shown in (Table 3). Ogoloncho (4.86) and Abola (4.55) had higher number of effective tillers per plant over the standard check and Tay, Shorima, Tsehay, Kingbird, Wane and Lemu. The higher effective tiller per plant, the higher could be grain yield. This is due to; effective tillers might have few to several grains which could directly related to yield. This is in agreement with the finding of Astawus et al. (2018) who reported significant variation for effective tillers per plant among the tested varieties. Further, Kifle et al. (2018) also reported significant variation among the tested varieties for the trait of effective tillers per plant.

Spike length $(\mathbf{c m})$ : Abola $(9.17 \mathrm{~cm})$ had longer spike length followed by Tay $(8.75 \mathrm{~cm})$ while Lemu $(6.25 \mathrm{~cm})$ had the shortest spike length. Spike length mean values ranged from $6.25 \mathrm{~cm}$ to $9.17 \mathrm{~cm}$. The reason for this much spike length difference might be due to the presence of genetic difference among varieties. The varieties which had longest spike length attributed to higher grain yield, number of grains per spike and spikelets per spike. This might be due to the reason that the positive association of spike length with those traits or a direct influence on the increase or decrease of yield components. This result is in agreement with the finding of (Assaye et al., 2013), who studied participatory varietal selection on wheat and he stated that the spike length difference ranged from $9.8 \mathrm{~cm}$ for variety ETBW5526 and $7.8 \mathrm{~cm}$ for Millennium variety.

Number of spikelet per spike: Abola (19.58) and Tay (19.08) followed by Ogoloncho (18.21) showed higher number of spikelet per spike while Lemu (15.5) and Wane (15.83) had few number of spikelet per spike. This is due to the fact that, when the length of spike increases, number of spikelets per spike increased, the number of grains per spike may increase and as a result the grain yield can increase. Similarly, the present result is supported by Kifle et al. (2018) and Assaye et al. (2013) who reported that larger spike length has a direct effect or contribution for higher number of spikelets. On other hand, non-significant variations among the tested bread varieties for spikelets per spike was reported by (Obsa et al., 2018).

Number of grain per spike: The highest number of grain per spike was recorded for Abola (57) followed by Tay (55) and Ogoloncho (49.33) while the lowest number of kernels was recorded for Lemu (37.33) (Table 3). In line with the present result, Mitiku and Regassa, (2019) reported that highest numbers of grains per spike were counted for Ogoloncho (37.3) over the other varieties under study.

Above ground dry biomass yield (ton $\mathbf{h a}^{-1}$ ): The mean values of biomass yield ranged from 7.6 to 11.3 -ton ha- ${ }^{1}$. Abola (11.27-ton ha $^{-1}$ ) and Ogoloncho (11.08-ton ha-1) recorded higher above ground biomass followed by Tay (10.50-ton $\left.\mathrm{ha}^{-1}\right)$ and Shorima (10.11-ton ha- $\left.{ }^{1}\right)$ whereas Lemu (7.66-ton ha- $\left.{ }^{1}\right)$ followed by Wane (8.29- ton ha1) recorded lower biomass yield among the varieties (Table 3). Abola and Ogoloncho had best performance while Lemu and Wane showed low and least performance for above ground biomass yield. This could be due to their stiff and hard stalks, large spikes, higher number of grains per spike and could result higher biomass yield. Similarly, higher biomass of Abola and Ogoloncho could be due to, they had longest plant height, higher tiller, large spike length and those traits could be contributed for higher biomass yield. Accordingly, varieties which showed lower biomass yield also had short plant height, fewer tiller, short spike length and resulted lower biomass. Therefore, biomass yield was significantly influenced by plant height, tiller number and spike length. Likewise, Yetsedaw et al. (2013), reported that, there was highly significant difference $(\mathrm{p}<0.01)$ in biomass yield on malt barley genotypes. According to his result the tasted genotypes mean value of biomass yield ranged from 3.1 to 5.8 t/ha.

Thousand kernel weight (gram): highest thousand seed weight was (38.95g) for Abola followed by Ogoloncho (38.80g) and Tay (37.00g) but, a lowest was Lemu (32.31g). Even though, variety Abola and Ogoloncho had better thousand seed weight in the study area, they are still under mean weight of thousand seeds for bread Wheat studied in India which was $46.18 \mathrm{~g}$ with a standard error of $( \pm 0.36 \mathrm{~g})$ (Deivasigamani and Swaminathan, 2018).

Grain yield (ton ha- $\left.{ }^{1}\right)$ : Abola (3.99ton ha ${ }^{-1}$ ) followed by Ogoloncho (3.87ton ha ${ }^{-1}$ ) was higher grain yielder while Wane (1.93ton $\mathrm{ha}^{-1}$ ) was the lower grain yielder. Astawus et al. (2018) reported that higher grain yield was observed by the variety Abola (6.4ton/ha) and Shorima (6.3ton/ha) over 25 varieties of under study. In contrary, Assefa et al. (2014) and Mitiku and Regassa (2019) reported that Picaflour/Kekeba gave very significantly higher grain yields than the check as well as the other varieties tested in the study. Likewise, Mitiku and Regassa, (2019) reported that maximum grain yield was recorded on improved bread wheat variety of Ogoloncho with productivity of $(2746 \mathrm{Kg} / \mathrm{ha})$ in Madda Walabu District Bale Zone of South Eastern Ethiopia.

Harvest index (\%): Abola (35.44\%) showed the highest harvest index followed by Ogoloncho (34.94\%), Shorima (30.02) and Tay (30.44\%) whereas Wane (23.22\%) had the lowest harvest index. The probable reason for higher harvest index of Abola, Ogoloncho and Shorima could be due to their better performance to disease reaction and genetic makeup that enable the varieties to have higher harvest index. Similar results for harvest index was also obtained by several authors (Assaye et al., 2013, Obsa and Yared, 2017 and Assefa et al., 2014) who reported that higher harvest index was obtained from disease resistant and well performing varieties. According to the study conducted by Astawus et al. (2018), the highest ratio of grain to biomass (HI) was observed from variety 
Kingbird (42.3\%), Kekeba (42.1\%)and Shorima (40.9\%) over the other varieties studied.

\section{c. Quality traits:}

Analysis of variance (ANOVA) of quality traits of the varieties exhibited significant variation $(\mathrm{P}<0.05)$ for hectoliter weight and protein content (Table 2). The mean separation table of hectoliter weight and protein content traits are presented on (Table 3).

Hectoliter weight $(\mathbf{K g} / \mathbf{h l})$ : Abola $(78.16 \mathrm{~kg} / \mathrm{hl})$ followed by Ogoloncho $(76.63 \mathrm{~kg} / \mathrm{hl})$ scored the highest hectoliter weight and Wane $(69.43 \mathrm{~kg} / \mathrm{hl})$ and Lemu $(69.46 \mathrm{~kg} / \mathrm{hl})$ both scored the lowest weight. In addition to inherent characteristics of the varieties, effects of disease incidence especially in grain filling period, could affect the weight of the seeds i.e. the bulk density of the wheat seed, especially for those susceptible varieties, and thus, they had showed lowest thousand seed weight and hectoliter weight of the varieties. Astawus Esatu (2016) reported also that hectoliter weight was highly significantly affected by the varieties and higher hectoliter weight was recorded from varieties Bika (75.51 kg/hl), Shorima (74.48 kg/hl), Mekelle-1 (73.98 kg/hl) and Jefferson, (73.97 kg/hl) in two districts of Arsi Zone Ethiopia.

Protein content (\%): The highest protein content was found on Abola (14.46\%). Proteins are important in determining the nutritional value of wheat, for both human and animal consumption, and are the main factors of baking quality. The protein content of wheat varies between 10 and 20\%; wheat for bread has 10-15\%, for pasta 11-17\% (Uthaya et al. 1999). Bordes et al. (2008) reported similar results of a larger range of grain protein content of $10.9-19.2 \%$ among the varieties tested in different locations. Because grains were collected from plants grown under different conditions in field trait at each location during the same growing season, the influence of environmental factors and/or varietal variation could be the factors for such variation of the total grain protein.

Table 3. Mean separation of 14 different phenological, growth and quality traits for 10 alternative bread wheat varieties at Guay kebele, D/Elias district in 2018/19

\begin{tabular}{|c|c|c|c|c|c|c|c|c|c|c|c|c|c|c|}
\hline Varieties & DE & DH & DM & $\begin{array}{l}\text { PH } \\
\text { (cm) }\end{array}$ & ETN & $\begin{array}{l}\text { SL } \\
\text { (cm) }\end{array}$ & SPS & GPS & $\begin{array}{l}\text { BY } \\
\text { t-ha }^{-1}\end{array}$ & $\begin{array}{l}\text { GY } \\
\text { t-ha }^{-1}\end{array}$ & $\begin{array}{l}\text { TKW } \\
\text { (g) }\end{array}$ & $\begin{array}{l}\text { HI } \\
(\%)\end{array}$ & $\begin{array}{l}\text { HLW } \\
\text { Kg/hl }\end{array}$ & $\begin{array}{l}\text { PC } \\
(\%)\end{array}$ \\
\hline Ogoloncho & $7.6 \mathrm{bc}$ & $67.3 b c$ & $116 \mathrm{ab}$ & $88.7 b c$ & $4.86 \mathrm{a}$ & $8.2 \mathrm{~b}$ & $18.2 \mathrm{~b}$ & $49.3 \mathrm{bc}$ & $11.1 \mathrm{a}$ & $3.87 \mathrm{a}$ & $38.8 \mathrm{a}$ & $34.94 a$ & $38.5 \mathrm{ab}$ & $15.4 \mathrm{ab}$ \\
\hline Tsehay & $6.3 \mathrm{de}$ & $65.3 b c$ & $108.6 \mathrm{c}$ & $81.8 \mathrm{de}$ & $3.1 \mathrm{~cd}$ & $6.8 \mathrm{c}$ & 16.3def & $46.6 \mathrm{cde}$ & $9.3 \mathrm{bc}$ & $2.8 \mathrm{bc}$ & 34 cde & $28.5 \mathrm{bc}$ & $38.3 \mathrm{ab}$ & $15.4 \mathrm{ab}$ \\
\hline Shorima & $7.6 b c$ & $66.6 \mathrm{bc}$ & $98.0 \mathrm{~d}$ & $78.8 \mathrm{ef}$ & $3.1 \mathrm{~cd}$ & $7.2 \mathrm{c}$ & $17.0 \mathrm{~cd}$ & $47.6 \mathrm{~cd}$ & $10 \mathrm{ab}$ & $2.9 \mathrm{bc}$ & $34.3 \mathrm{~cd}$ & $30.0 \mathrm{ab}$ & $38.0 \mathrm{ab}$ & $15.2 \mathrm{ab}$ \\
\hline $\begin{array}{l}\text { Kekeba } \\
\text { (Check) }\end{array}$ & $5.6 \mathrm{e}$ & $58.0 \mathrm{e}$ & $92.0 \mathrm{e}$ & $\begin{array}{l}84.3 \\
\mathrm{~cd}\end{array}$ & $2.6 \mathrm{~d}$ & $7.2 \mathrm{c}$ & 16.1 efg & $43 \mathrm{def}$ & $9.2 \mathrm{bc}$ & $2.6 \mathrm{bcd}$ & $34.5 \mathrm{~cd}$ & $29.3 b$ & $35.9 b$ & $14.6 \mathrm{~b}$ \\
\hline Danda'a & $8.6 \mathrm{a}$ & $69.0 \mathrm{~b}$ & $114 \mathrm{~b}$ & $89.8 \mathrm{ab}$ & $3.4 \mathrm{c}$ & $7.3 \mathrm{c}$ & $17.5 \mathrm{c}$ & $48.3 \mathrm{~cd}$ & $9.3 \mathrm{bc}$ & $2.6 \mathrm{~cd}$ & $35.4 b c$ & $27.2 \mathrm{bc}$ & $37.3 \mathrm{ab}$ & $15.1 \mathrm{ab}$ \\
\hline Tay & 8.0ab & $68.0 \mathrm{bc}$ & $115 \mathrm{ab}$ & $94.5 \mathrm{a}$ & $3.9 \mathrm{~b}$ & $8.7 \mathrm{ab}$ & $19.1 \mathrm{a}$ & $55.0 \mathrm{ab}$ & $10.5 \mathrm{ab}$ & $3.18 \mathrm{~b}$ & $37.0 \mathrm{~b}$ & $30.4 \mathrm{ab}$ & $38.2 \mathrm{ab}$ & $15.5 \mathrm{ab}$ \\
\hline King bird & $7.3 \mathrm{de}$ & $66.6 \mathrm{bc}$ & $107 \mathrm{c}$ & 82.4de & $3.4 \mathrm{c}$ & $7.3 \mathrm{c}$ & $17 \mathrm{cde}$ & $44.6 \mathrm{cde}$ & $9.2 \mathrm{bc}$ & $2.6 \mathrm{bcd}$ & $33.5 \mathrm{de}$ & $28.7 b c$ & $37.9 \mathrm{ab}$ & $15.2 \mathrm{ab}$ \\
\hline Lemu & $7.0 \mathrm{~cd}$ & $75.0 \mathrm{a}$ & $114 \mathrm{~b}$ & $76.3 \mathrm{fg}$ & $3.4 \mathrm{c}$ & $6.2 \mathrm{~d}$ & $15.5 \mathrm{~g}$ & $37.33 \mathrm{f}$ & $7.66 \mathrm{~d}$ & 2.1ed & $32.31 \mathrm{e}$ & $27.3 b c$ & $42.2 \mathrm{ab}$ & $15.5 \mathrm{ab}$ \\
\hline Wane & $6.3 \mathrm{de}$ & $62.0 \mathrm{~d}$ & $107.6 \mathrm{c}$ & $71.8 \mathrm{~g}$ & $2.8 \mathrm{~d}$ & $7.2 \mathrm{c}$ & $15.8 \mathrm{fg}$ & $41.3 \mathrm{ef}$ & $8.3 \mathrm{~cd}$ & $1.9 \mathrm{e}$ & 33.0de & $23.22 \mathrm{c}$ & $35.5 b$ & $14.6 \mathrm{~b}$ \\
\hline Abola & $8.3 \mathrm{ab}$ & $69.0 \mathrm{~b}$ & $118 \mathrm{a}$ & $94.5 \mathrm{a}$ & $4.5 \mathrm{a}$ & $9.2 \mathrm{a}$ & $19.6 \mathrm{a}$ & $57.66 \mathrm{a}$ & $11.3 \mathrm{a}$ & $4.0 \mathrm{a}$ & $38.9 \mathrm{a}$ & $35.44 \mathrm{a}$ & $40.9 \mathrm{ab}$ & $16.9 \mathrm{a}$ \\
\hline Sig. diff. & $* *$ & $* *$ & $* *$ & $* *$ & $* *$ & $* *$ & $* *$ & $* *$ & $* *$ & $* *$ & $* *$ & $*$ & * & $*$ \\
\hline $\mathbf{S E} \pm$ & 0.38 & 1.40 & 1.44 & 2.48 & 0.24 & 0.27 & 0.32 & 2.98 & 0.66 & 0.28 & 0.82 & 2.69 & 2.63 & 0.87 \\
\hline CV & 6.15 & 2.57 & 1.61 & 3.60 & 7.46 & 4.47 & 2.27 & 7.76 & 8.40 & 12.11 & 2.86 & 11.17 & 8.41 & 6.89 \\
\hline
\end{tabular}

Where, $D E=$ days to $50 \%$ emergence, $D H=$ days to $75 \%$ heading/flowering, DM =, days to $90 \%$ maturity, $P H=$ plant height, ETN=effective tiller number, SPS $=$ spikelet per spike, $S P L=$ spike length, $N G S=$ number of grains per spike, $B Y=$ biomass yield, $G Y=$ Grain yield, $T K W=$ thousand kernel weight, $H I=$ harvest index, $H L W=$ hectoliter weight, $P C=$ protein content, $C V=$ coefficient of variance, $S E=$ standard error, $*=$ significantly different $(P<0.05), * *=$ highly significantly different $(P<0.01)$.

\subsection{Variability components and coefficient of variation}

According to Burton and De Vane (1953), PCV and GCV values roughly more than $20 \%$ are regarded as high, whereas values less than $10 \%$ are considered to be low and values between 10 and $20 \%$ to be medium. Based on this bench mark, genotypic coefficient of variance was maximum for hectoliter weight (79.27) and minimum for grain yield $(1.82 \%)$. The highest genetic coefficient of variance $(>20 \%)$ was estimated from hectoliter weight (79.27) and moderate genotypic coefficient of variance (10-20\%) was obtained from harvest index $(10.33 \%)$, biomass yield (11.02\%), grain per spike (12.69\%), spike length (11.67\%), effective tiller (15.73\%) and days to $50 \%$ emergence $(13.53 \%)$. this suggesting that the genotype could be reflected by the phenotype and the effectiveness of selection based on the phenotypic performance for these characters. In line with the present result, Birhanu et al. (2016) reported moderate GCV of harvest index, biomass yield, grain per spike and effective tiller on bread wheat varieties. In contrary to this study, Gour et al., (2017) reported high genotypic and phenotypic coefficient of variation for seed yield per plant, days to $50 \%$ flowering, biological yield per plant, spikelets/plant, harvest index, number of tillers/plant and plant height on rice

Lower genetic coefficient of variance $(<10 \%)$ was obtained from days to heading, days to $90 \%$ maturity, plant height, spikelets per spike, grain yield, hectoliter weight and protein content (Table 4). High PCV was estimated from TKW (88.25) and ETN (26.94\%) and moderate PCV was obtained from days to 50\% maturity (14.83\%), harvest index (15.21\%), grain per spike (14.37\%), biomass yield (13.85\%) and from spike length $(12.28 \%)$ but lower PCV $(<10 \%)$ also estimated from days to $75 \%$ heading, days to $90 \%$ maturity, plant height, spikelets per spike, grain yield, hectoliter weight and protein content. Likewise, Ali et al. (2012) reported medium PCV and GCV for grain yield per plot in 20 bread wheat genotypes. Furthermore, Sentayehu et al. (2015) reported high PCV and GCV in traits of number of tillers plant-1, spike length, kernel per spike, thousand-grain weight, biomass yield per plot, harvest index, and grain yield per plot. The higher PCV and GCV values for most of the characters 
could be evidence for the existence of a wide range of variation for such characters.

Phenotypic coefficient of variation for all the traits was relatively higher than the genotypic coefficient of variation (Table 4.) which indicates the presence of little influence of environment in the expression of these metric traits. In general, the PCV values for most characters were closer with the corresponding GCV values showing little environment effect on the expression of these characters but higher variation between GCV and PCV was observed on effective tiller $(\mathrm{GCV}=15.73 \%, \mathrm{PCV}=26.94 \%)$ and thousand kernel weight $(\mathrm{GCV}=79.07 \%$, PCV $=88.25 \%$ ) (Table 4). Similar results were also observed by Mohammed et al. (2011) and Subhashchandra et al. (2009), who reported that higher variation between phenotypic coefficient of variance and genotypic coefficient of variance was observed for effective tiller and thousand kernel weight traits. Therefore, selection of verities based on a phenotypic basis for effective tiller and thousand kernel weight may not be effective in the genetic improvement of such traits due to influence of the environment or growing condition on the varieties.

The traits which showed lower PCV and GCV values implying the difficulty of improving these traits through simple selection. However, contradicting results were obtained from the works of Tazeen et al. (2009) who found that wide range between PCV and GCV for thousand seed weight in durum wheat. The high PCV and GCV value with little difference indicates that selection may be effective based on these traits.

High ECV was estimated from two traits thousand kernel weight (36.67\%) and effective tiller $(21.88 \%)$ out of fourteen traits and moderate ECV was also observed from single trait harvest index $(11.17 \%)$ whereas all traits except effective tiller and thousand kernel weight had minimum ECV. From this trial there was great variability in the traits under the studied varieties of bread wheat. The traits which showed low ECV was not influenced by the environment i.e. the influence of environment on those characters was lower and phenotypic selection could be effective.

Table 4. Variance, genotypic and phenotypic coefficient of variability of 14 traits of bread wheat varieties tested at Guay Kebele (2018/19)

\begin{tabular}{llllllllllll}
\hline Traits & MSt & Mse & GM & GV & EV & PV & $\begin{array}{l}\text { GCV } \\
(\%)\end{array}$ & $\begin{array}{l}\text { PCV } \\
(\%)\end{array}$ & $\begin{array}{l}\text { ECV } \\
(\%)\end{array}$ & $\begin{array}{l}\mathbf{h}^{2} \mathbf{b} \\
\text { \% }\end{array}$ & GA \\
\hline DE & 3.05 & 0.19 & 7.20 & 0.95 & 0.19 & 1.14 & 13.53 & 14.83 & 6.05 & 83.33 & 1.83 \\
DH & 60.40 & 2.95 & 66.70 & 19.15 & 2.95 & 22.10 & 6.56 & 7.04 & 2.57 & 86.65 & 8.40 \\
DM & 213.41 & 3.12 & 109.10 & 70.09 & 3.12 & 73.21 & 7.66 & 7.84 & 1.62 & 95.74 & 16.87 \\
PH & 172.35 & 9.23 & 84.33 & 54.37 & 9.23 & 63.60 & 8.71 & 9.45 & 3.60 & 85.49 & 14.04 \\
ETN & 1.53 & 0.6 & 3.54 & 0.31 & 0.60 & 0.91 & 15.73 & 26.94 & 21.88 & 34.07 & 0.67 \\
SPL & 2.37 & 0.11 & 7.55 & 0.75 & 0.11 & 0.86 & 11.47 & 12.28 & 4.39 & 87.21 & 1.66 \\
SPS & 5.66 & 0.15 & 17.21 & 1.83 & 0.15 & 1.98 & 7.86 & 8.17 & 2.25 & 92.42 & 2.68 \\
NGS & 110.81 & 13.36 & 47.10 & 32.46 & 13.36 & 45.82 & 12.09 & 14.37 & 7.76 & 70.84 & 10.94 \\
BY & 4.00 & 0.65 & 9.60 & 1.12 & 0.65 & 1.77 & 11.02 & 13.85 & 8.39 & 63.28 & 1.73 \\
GY & 1.35 & 0.12 & 35.16 & 0.41 & 0.12 & 0.51 & 1.82 & 2.01 & 0.98 & 80.39 & 1.18 \\
TKW & 16.44 & 1.01 & 2.86 & 5.14 & 1.01 & 6.15 & 79.27 & 88.25 & 36.67 & 83.58 & 4.26 \\
HI & 38.82 & 10.88 & 29.53 & 9.31 & 10.88 & 20.19 & 10.33 & 15.21 & 11.17 & 46.11 & 4.27 \\
HLW & 25.08 & 0.29 & 73.27 & 8.26 & 0.29 & 8.55 & 3.92 & 3.99 & 0.73 & 96.61 & 5.82 \\
PC & 0.99 & 0.71 & 13.00 & 0.09 & 0.71 & 0.80 & 2.30 & 6.88 & 6.50 & 11.25 & 0.2 \\
\hline
\end{tabular}

Where, $D E=$ days to $50 \%$ emergence, $D H=$ days to $75 \%$ heading/flowering, $D M=$, days to $90 \%$ maturity, $P H=$ plant height, ETN= effective tiller number, $S P S=$ spikelet per spike, $S P L=$ spike length, NGS= number of grains per spike, $B Y=$ biomass yield, GY= Grain yield, $T K W=$ thousand kernel weight, $H I=$ harvest index, HLW= hectoliter weight, $P C=$ protein content, $h^{2} b=$ broad sense heritability, GA=genetic advance, Mst= mean square due to treatment/genotype, Mse= mean square due to error, GM= grand mean, $G V=$ genotypic variance, EV= environmental variance, $P V=$ phenotypic variance, $G C V=$ genotypic coefficient of variance, $E C V=$ environmental coefficient of variance, $P C V=$ phenotypic coefficient of variance.

\subsection{Heritability $\left(\mathrm{H}^{2}\right)$ and Genetic Advance}

The estimates of heritability and genetic advance for mother and baby trials presented in (Table 4). In the mother trial, the highest heritability of $93.93 \%$ was exhibited by biomass yield and the lowest heritability was exhibited by wet gluten $(24.81 \%)$. According to Singh, (2001), if heritability of a character is (high, $\mathrm{h}^{2} \geq 80 \%$, moderate (40 to $80 \%)$, low if $\left.h^{2}<40 \%\right)$. Considering this benchmark, heritability estimate was high $(>80 \%)$ for days to $50 \%$ emergence, days to heading, plant height, biomass yield, thousand kernel weight, spikelet per spike, harvest index, stem rust and leaf rust. For those traits which showed high heritability, selection could be easy. This is because there would be a close correspondence between the genotype and the phenotype due to the relative small contribution of the environment to the phenotype.

The heritability estimate ranged between $11.25 \%$ (protein content) and $96.61 \%$ (hectoliter weight). High heritability $(>80 \%)$ estimate was observed from DE, DH, DM, PH, SPL, SPS, GY, TKW, HLW and moderate heritability (40-80\%) was observed from HI, BY and NGS but low heritability $(<40 \%)$ was showed from ETN and 
PC. High heritability related to time to heading and thousand grain weight were obtained in the studies conducted previously (Tazeen et al., 2009). Higher heritability of the most important trait i.e. grain yield, plant height, spikelet per spike, grain per spike, biomass yield, thousand grain weight and harvest index was high, this clearly indicating higher influence of genetic factors than the environment on the expression of this trait. Likewise, Khan et al. (2017), reported high heritability estimates for plant height, number of spikelets spike ${ }^{-1}$, spike length, number of grains spike $^{-1}, 1000$ grain weight and yield. Further, this finding is supported by the findings of Kashif and Khaliq (2004) and Haq et al. (2008). Estimation of different genetic parameters has imperative advantage to study the genetic basis of different traits that can contribute to crop yield. The high heritability magnitude indicates the reliability with which the high chance of the genotype to be recognized by its phenotypic expression. The traits which showed low heritability $(\mathbf{<} \mathbf{4 0} \%)$ values suggesting, selection for these characters would not be effective due to predominant effects of non- additive genes in this population. Contradict results obtained by the previous studies i.e. low heritability for biological yield and grain yield were recorded in durum wheat genotypes that were evaluated previously (Kahrizi et al., 2010).

\section{Genetic advance (GA)}

Estimates of GA for all studied traits of the bread wheat varieties presented in (Table 4). Moderate genetic advance was observed from days to $90 \%$ maturity, plant height and number of grains per spike while the rest traits showed low genetic advance $(<10 \%)$ (Table 4$)$. In this trial, no trait showed higher genetic advance. However, those traits which showed moderate genetic advance together with traits which had higher heritability could be most important traits for selection in the breeding program. Kumar et al. (2014) also evaluated thirty genotypes of bread wheat and reported high genetic advance for plant height, biological yield per plant and moderate for harvest index, test weight and low genetic advance was observed for days to $50 \%$ flowering and spike length.

In contrary to the present study, Ferdous et al. (2010) reported that, grains spike-1, grain yield, days to maturity, grains spike-1, grain yield, effective tillers plant-1, grains spike-1, 100-grain weight and grain yield showed high genetic advance. High heritability and high genetic advance indicates that preponderance of additive gene effect, therefore, characters can be better exploited through selection (Harshwardhan et al., 2016).

\subsection{Correlation among traits}

Grain yield revealed strong, positive and highly significant correlation with most important agronomic traits, harvest index $\left(\mathrm{HI}, \mathrm{r}=0.88^{* *}\right)$, plant height $\left(\mathrm{PH}, \mathrm{r}=0.67^{* *}\right)$, number of effective tillers $\left(\mathrm{ETN}, \mathrm{r}=0.73^{* *}\right)$, spike length ( $\left.\mathrm{SL}, \mathrm{r}=0.74^{* *}\right)$, spikelet per spike (SPS, $\mathrm{r}=0.70^{* *}$ ), number of grain per spike ( $\mathrm{NGS,} \mathrm{r}=0.80^{* *}$ ), biomass yield (BY, $\mathrm{r}=0.85^{* *}$ ), 1000 seed weight (TSW, $\mathrm{r}=0.76^{* *}$ ) and hectoliter weight (HLW, $\mathrm{r}=0.83^{* *}$ ). (Table 4.14). On the other hand, grain yield had weak, positive and significant correlation with days to $50 \%$ emergence (DE, $\left.\mathrm{r}=0.41^{*}\right)$ while weak, positive and insignificant correlation with days to heading $(\mathrm{DH}, \mathrm{r}=0.10 \mathrm{~ns})$, days to maturity $(\mathrm{DM}, \mathrm{r}=0.34 \mathrm{~ns})$ and protein content $(\mathrm{PC}, \mathrm{r}=0.27 \mathrm{~ns})$ (Table 5).

The grain quality traits i.e. protein content showed positive and significant association with days to $75 \%$ heading while weak and non-significant correlation with days to $50 \%$ emergence, days to $90 \%$ maturity, biomass yield, thousand kernel weight, grain yield, harvest index and hectoliter weight. From previous literature, significant and positive correlations of yield with other agronomic traits were observed i.e. number of effective tillers per plant with 1000 grain weight (Rahman et al., 2016) which was in agreement with this study in which the correlation analysis showed that positive correlation among agronomic traits such as effective tillers per plant, plant height,1000-grain weight, spike length, spikelet per spike, biomass yield, harvest index, hectoliter weight and grains per spike.

The positive associations of those important agronomic traits with grain yield explained that varieties which had high number of tillers per plant, number of grains per spike, more effective tillers, large spike length, high hectoliter weight, more spikelet per spike, biomass yield, 1000-seed weight and harvest index resulted in high grain yield production. Likewise, this result is in agreement with the result obtained by (Assefa et al., 2014). Similar result also reported by Astawus Esatu, (2016) who obtained positive, strong and highly significant correlation of grain yield with days to heading, days to maturity, plant height, number of fertile tillers, spikelet per spike and spike length. This also in agreement with the report of Khan et al., (2007) i.e. positive significant correlation was found for spike length, number of spikelets spike-1, grain yield plant-1 and 1000-grain weight with yield (kg ha-1).

Molla et al. (2011), also indicated that the number of grain per spike, 1000 kernel weight and biological yield had the most direct and positive effect on grain yield. Parallely, Shamsi et al. (2011) also showed that the most important yield component on grain yield is number of grains per spike followed by number of spikes per meter square and 1000 kernel weight. Budak (2000) and Yagdi and Sozen, (2009) also reported the high and positive correlation of grain yield with number of tillers per plant, thousand grain weight, biological yield and harvest index and recommended these traits as selection criteria in durum wheat. 
Table 5. Pearson's correlation coefficient ( $r$ ) for all traits of the tested bread wheat varieties in 2018/2019.

\begin{tabular}{|c|c|c|c|c|c|c|c|c|c|c|c|c|c|c|}
\hline Traits & DE & DH & DM & PH & ETN & SL & SPS & NGS & BY & TKW & GY & HI & HLW & PC \\
\hline DM & $0.56^{* *}$ & $0.66^{* *}$ & 1.00 & & & & & & & & & & & \\
\hline PH & $0.53 * *$ & $0.12 \mathrm{~ns}$ & $0.42 *$ & 1.00 & & & & & & & & & & \\
\hline SL & $0.58^{* *}$ & $0.32 \mathrm{~ns}$ & $0.48 * *$ & $0.78 * *$ & $-0.45^{* *}$ & 1.00 & & & & & & & & \\
\hline SPS & $0.59 * *$ & $0.24 \mathrm{~ns}$ & $0.47 * *$ & $0.82 * *$ & $0.72 * *$ & $0.88 * *$ & 1.00 & & & & & & & \\
\hline NGS & $0.23 \mathrm{~ns}$ & $-0.14 \mathrm{~ns}$ & $0.23 \mathrm{~ns}$ & $0.46^{* *}$ & $0.44 *$ & $0.55^{* *}$ & $0.51^{* *}$ & 1.00 & & & & & & \\
\hline GY & $0.41 *$ & $0.10 \mathrm{~ns}$ & $0.34 \mathrm{~ns}$ & $0.67 * *$ & $0.73 * *$ & $0.74 * *$ & $0.70^{* *}$ & $0.80 * *$ & $0.85 * *$ & $0.76^{* *}$ & 1.00 & & & \\
\hline HI & $0.38^{*}$ & $0.15 \mathrm{~ns}$ & $0.22 \mathrm{~ns}$ & $0.53^{*}$ & $0.62 * *$ & $0.61 * *$ & $0.57 * *$ & $0.28^{*}$ & $0.53 * *$ & $0.61^{* *}$ & $0.88^{* *}$ & 1.00 & & \\
\hline HLW & $0.29^{*}$ & $0.02 \mathrm{~ns}$ & $0.29 \mathrm{~ns}$ & $0.80^{*}$ & $0.70^{* *}$ & $0.79 * *$ & $0.77 * *$ & $0.68 * *$ & $0.75^{* *}$ & $0.88^{* *}$ & $0.83 * *$ & $0.68 * *$ & 1.00 & \\
\hline PC & $0.23 \mathrm{~ns}$ & $0.08 \mathrm{~ns}$ & $0.22 \mathrm{~ns}$ & $0.14 *$ & $0.27 \mathrm{~ns}$ & $0.34 \mathrm{~ns}$ & $0.43 *$ & $0.40^{*}$ & $0.31 \mathrm{~ns}$ & $0.26 \mathrm{~ns}$ & $0.27 \mathrm{~ns}$ & $0.11 \mathrm{~ns}$ & $0.32 \mathrm{~ns}$ & 1.00 \\
\hline
\end{tabular}

Where, $D E=$ days to $50 \%$ emergence, $D H=$ days to $75 \%$ heading, DM =, days to $90 \%$ maturity, $P H=$ plant height, ETN $=$ effective tiller number, SPS $=$ spikelet per spike, $S P L=$ spike length, $N G S=$ grains per spike, $B Y=$ biomass yield, GY= Grain yield, TKW= thousand kernel weight, $H I=$ harvest index, $H L W=$ hectoliter weight, $P C=$ protein content, $* *=$ highly significantly $(P \leq 0.01), *=$ significantly $(P \leq 0.05)$ correlated, $n s=$ insignificant correlation and $(-)=$ negative sign for correlation among traits.

\section{CONCLUSION}

This study generally indicated that there was genetic variability among the varieties tested in the study area. This genetic variability could result good condition to select the best performing varieties and also create a great opportunity in the improvement of bread wheat varieties. The analysis of variance showed highly significant differences among varieties $(\mathrm{P}<0.01)$ were observed for Twelve characters (days to emergence, days to heading, days to maturity, plant height, effective tillers per plant, spike length, spikelets per spike, grain per spike, 1000 kernel weight, biomass yield, grain yield and hectoliter weight), significant at $(p<0.05)$ for the rest two characters; namely, harvest index and protein content. The highest grain yield was obtained from variety Abola (4.0ton ha $\left.{ }^{-1}\right)$ followed by Ogoloncho (3.87ton ha ${ }^{-1}$ ) while the lowest was recorded from Wane (1.9ton ha $\left.{ }^{-1}\right)$ followed by Lemu $\left(2.1\right.$ ton $\left.\mathrm{ha}^{-1}\right)$. Similarly, Abola recorded the highest protein content which was $(16.9 \%)$ the lower protein content was recorded from Wane (14.6\%) and Kekeba (14.6\%).

The genotypic and phenotypic coefficient of variability for most traits was similar in magnitude and directions that enable the genotypes to express their genetic potential. the maximum genotypic coefficient of variance recorded for hectoliter weight (79.27) and minimum for grain yield (1.82\%). Lower genetic coefficient of variance $(<10 \%)$ was obtained from days to heading, days to $90 \%$ maturity, plant height, spikelets per spike, grain yield, hectoliter weight and protein content and higher PCV was estimated from TKW (88.25) and ETN (26.94\%) but, the other traits showed moderate genotypic coefficient of variance. Grain yield, plant height, spikelet per spike, grain per spike, biomass yield, thousand grain weight and harvest index had higher heritability, suggesting that higher influence of genetic factors than the environment on the expression of this trait. Lower genetic coefficient of variance $(<10 \%)$ was obtained from days to heading, days to $90 \%$ maturity, plant height, spikelets per spike, grain yield, hectoliter weight and protein content and higher PCV was estimated from TKW (88.25) and ETN (26.94\%) but, the other traits showed moderate genotypic coefficient of variance. Grain yield, plant height, spikelet per spike, grain per spike, biomass yield, thousand grain weight and harvest index had higher heritability, suggesting that higher influence of genetic factors than the environment on the expression of this trait.

Grain yield revealed strong, positive and highly significant correlation with most important agronomic traits, harvest index ( $\left.\mathrm{HI}, \mathrm{r}=0.88^{* *}\right)$, plant height $\left(\mathrm{PH}, \mathrm{r}=0.67^{* *}\right)$, number of effective tillers (ETN, $\left.\mathrm{r}=0.73^{* *}\right)$, spike length (SL, $\mathrm{r}=0.74^{* *}$ ), spikelet per spike (SPS, $\mathrm{r}=0.70^{* *}$ ), number of grain per spike (NGS, $\mathrm{r}=0.80^{* *}$ ), biomass yield (BY, $\left.\mathrm{r}=0.85^{* *}\right), 1000$ seed weight (TSW, $\mathrm{r}=0.76^{* *}$ ) and hectoliter weight (HLW, $\mathrm{r}=0.83^{* *}$ ).

Generally, the tested varieties indicated the presence of variability in almost important agronomic and quality traits. Therefore, Abola and Ogoloncho had superior performance over the standard check and other varieties and this indicates that they would be used in multiplication, production as well as genetic resource for any crop improvement.

Therefore, the information generated from this study needs to be used by breeders who are interested in different traits. However, the present result is only an indication and cannot reach a definite conclusion. Therefore, since the experiment was carried out at one location in one season, it is advisable to continue with this study over several years and locations

\section{REFERENCES}

Abhilasha S, Anil K., Karuna S, Madan M., Ritu M, Raj K. 2018. Genetic variability, associations, and path analysis of chemical and morphological traits in Indian ginseng [Withania somnifera (L.) Dunal] for selection of higher yielding genotypes. Journal of Ginseng Research, 42 (158-164).

Ali, S., Khan, G., Zia Kumar B., Yousuf, M., Roomi, T. and Ahmad, M.F. 2013. Estimation of Genetic Diversity in Genetic Stocks of Common Wheat (Triticum aestivum L.) Using SDS-PAGE, Europ. Acad. R. 1:18611871. 
Allard, R.W.1960. principles of plant breeding. John Wiley and Sons Inc. New York Pp;229.

Assaye Demelash, Tadesse Desalegn, Getachew Alemayehu, 2013. Participatory Varietal Selection of Bread Wheat (Triticum aestivum L.) Genotypes at Marwold Kebele, Womberma Woreda, West Gojam, Ethiopia. International Journal of Agronomy and Plant Production. Vol 4 (S), Pp. 3543-3550.

Assefa Workineh, Birhanu Abate, and Demelash Kefalle. 2014. "Participatory Evaluation and Selection of Bread Wheat (Triticum aestivum L.) Varieties". World Journal of Agricultural Research. 2(6): 315-320.

Astawus Esatu, Firew Mekibib and Tadesse Dessalegn. 2018. Performance evaluation and farmer's selection criteria of improved bread Wheat varieties. African Journal of Agricultural Research, Vol. 13(44), pp. 2477 2498 .

Astawus Esatu. 2016. Participatory and Performance Evaluation of Improved Bread Wheat (Triticum aestivum L.) Varieties in Two Districts of Arsi Zone. M.Sc. thesis, Haromaya University, Haromaya, Ethiopia.

Bordes, J., Branlard, G., Oury, F.X., Charmet, G. and Balfourier, F. 2008. Agronomic characteristics, grain quality and flour rheology of 372 bread wheats in a worldwide core collection. J. Cereal Sci. 48: 569-579.

Budak N. 2000. Heritability, correlation and genotype x year interactions of grain yield, test weight and protein content in durum wheats. Turkish J. Field Crops. 5(2): 35-41

Burton, G.W. and E.H. Devane. 1953. Estimation of heritability in tall Festuca (Festuca arudindcea) from replicated colonial material. Agronomy Journal. 45:78-481.

Central Statistical Agency (CSA). 2017. Agricultural Sample Survey Report on Area and Production of Major Crops. The Federal Democratic Republic of Ethiopia. Volume I. Statistical Bulletin 584. CSA, Addis Ababa, Ethiopia.

Dawit Tsegaye, Tadesse Dessalegn, Yigzaw Dessalegn and Getnet Share. 2012. Genetic variability, correlation and path analysis in durum wheat germplasm (Triticum durum Desf). Agricultural Research and Reviews, Vol. 1(4), pp. $107-112$.

Debre Elias District Agriculture and Rural development office. 2005. Annual report on agricultural activities (in Amharic), planning and training service, Debre Elias.

Deivasigamani S., Swaminathan C., 2018. " Evaluation of seed test weight on major field crops", International journal of research studies in agricultural sciences, Vol. 4(1), pp. 08-11.

Falconer, D.S. and T. F.C. Mackay. 1996. Introduction to quantitative genetics (4th edition), Longman, New York.

Fano Dargo and Tadeos Shiferaw, 2017. Participatory Varietal Selection of Bread Wheat Cultivars (Triticum Aestivum L.) for Moisture Stress Environment of Somali Regional State of Ethiopia. Journal of Biology, Agriculture and Healthcare: Vol.7 (5):58-67.

Ferdous, M.F., Shamsuddin, A.K.M., Hasna, D. and Bhuiyan, M.M.R., 2010. Study on relationship and selection index for yield and yield contributing characters in spring wheat. Journal of Bangladesh Agricultural University 8(2): 191-194.

Figuera, M., Upadhyaya, N.M., sperschneider, J., Park, R.F., Szabo, L.j., Steffenson, B., Ellis, J.G and Dodds, P.N. 2016. Changing the game: using integrative genomics to probe virulence mechanisms of the stem rust pathogen Puccinia graminis f. sp. tritici. Front, plant scie.7, 205.

Food and Agriculture Production of the united nations (FAO), 2019. http://www.fao.org/worldfoodsituation. (accessed 09.05.19.)

Gour L, GK Koutu, SK Singh, DD Patel, A Shrivastava and Y Singh. 2017. Genetic variability, correlation and path analyses for selection in elite breeding materials of rice (Oryza sativa L.) genotypes in Madhya Pradesh. The Pharma Innovation Journal; 6(11): 693-696.

Hanson, G.H., Robinson, H.F. and Comstock, R.E. 1956. Biometrical studies of yield in segregating population of Korean Lespedeza. Agron. J., 48: 267-282.

Haq, U. W., Malik, M. F., Rashid, M., Munir, M. and Akram, Z. 2008. Evaluation and estimation of heritability and genetic advancement for yield related attributes in wheat lines. Pakistan Journal of Botany, 40: 16991702 .

Harshwardhan, Anil K, Amarjeet K and Birendra P. 2016. Study of variance, heritability and genetic advance for various yield contributing and quality traits in spring wheat (Triticum aestivum L.). Journal of Applied and Natural Science 8 (4): 1811-1814.

Johnson, H.W., Robinson, H.F. and R.E. Comstock. 1955. Estimation of genetic and environmental variability in soybean. Agron J. 47: 314-318

Kahrizi D, Cheghamriza K, Kakaei M, Mohammadi R, Ebadi A. 2010. Heritability and genetic gain of some morpho-physiological variables of durum wheat (Triticum turgidum var. durum). Afr. J. Biotechnol., 9(30): 4687-4691

Kashif, M., and Khaliq,I. 2004. Heritability, correlation and path coefficient analysis for some metric traits in wheat. International Journal of Agriculture and Biology, 6: 138-142

Khan G., Shikari A., Wani. S. and Vaishnavi, R. 2017. Variability Parameters in Wheat- A Review, Int. J. Pure 
App. Biosci. 5(4): 651-662). doi: http://dx.doi.org/10.18782/2320-7051.2638.

Khan, M.M., Khan, Q., Khan, R.D. and Rabani, M.A., 2007. Correlation and phenotypic variability studies for some agronomic traits among bread wheat (Triticum aestivum L.) accessions. Gomal University Journal of Research, 23(2): 18-24.

Kifle Zerga, Birhanu Tsegaye, Mekonen Gebru. 2018. Farmers participatory and selection of bread wheat Triticum Aestivum. L) varieties in cheha district, Gurage Zone, Ethiopia. Internaltional journal of scientific and research publications, Vol 8(12).

Kifle Zerga, Firew Mekbib, Tadesse Dessalegn. 2016. Genetic Variability, Heritability and Genetic Advance in Bread Wheat (Triticum aestivum. L) Genotypes at Gurage Zone, Ethiopia. International Journal of Microbiology and Biotechnology. Vol. 1(1), pp. 1-9.

Kifle Zerga, Firew Mekbib, Tadesse Dessalegn. 2017. The Mean Performance of Different Bread Wheat (Triticum Aestivum. L) Genotypes in Gurage Zone, Ethiopia. Landscape Architecture and Regional Planning. Vol. 2, No. 1, pp. 29-35.

Kumar, R.., Bharti, S., Kumar, A. and Nagar, S. S. 2014. Genetic variability, heritability and genetic advance in bread wheat. Environment and Ecology, 31 (v): 405-407

Larik AS, Malik SI, Kakar AA, Naz MA, 2000. Assessment of heritability and genetic advance for yield and yield components in Gossypium hirsutum L. Scientific Khyber. 13: 39-44.

Mohammed A, Amsalu A, Geremew. 2011. Genetic variability, heritability and trait association in durum wheat (Triticum turgidum L. var. durum) genotypes. Afri. J. Agric. Res., 6(17): 3972-3979.

Molla, M. V., Imani A.A., Shahryari, R. and Khayatnezhad, M. 2011. Correlation and path analysis of morphological traits in different wheat genotypes under end drought stress condition. Mid-East Journal of Science and Research. (2):221-224.

Obsa Chimdesa and Yeared Tesfaye. 2017. Participatory Variety Selection of Improved Bread Wheat Varieties for High Land Guji Zone, Southern Ethiopia. Journal of Biology, Agriculture and Healthcare. Vol.7(7).

Obsa Chimdesa, Kabna Aseffa, Seyum Alemu. 2018. Participatory Variety Selection of Improved Bread Wheat Varieties for Moisture Stress Areas of Guji Zone, Southern Oromia. International Journal of Research in Agriculture and Forestry, Volume 5(4), PP 1-6.

Rahman, M., Barma, N. C. D., Biswas, B. K., Khan, A. A. and Rahman, J. 2016. Study on morpho-physiological traits in spring wheat (Triticum aestivum L.) under rain fed condition. Bangladesh Journal of Agricultural Research, 41:2.

Singh, B.D. 2001. Plant breeding: principle and methods. Kalyani publishers, New Delhi, 896p.

Subhashchandra B, Lohithaswa HC, Desai SA, Hanchinal RR, Kalappanavar IK, Math KK, Salimath PM .2009. Assessment of genetic variability and relationship between genetic diversity and transgressive segregation in tetraploid wheat. Karnataka J. Agric. Res., 22(1): 36-38.

Tazeen M, Nadia K, Farzana NN. 2009. Heritability, phenotypic correlation and path coefficient studies for some agronomic characters in synthetic elite lines of wheat. J Food Agr Environ., 7(3\&4): 278-282.

Uthaya S, Gras P, Stoddard FL, Bekes F. 1999. Effect of varying protein content and glutenin to gliadin ratio on the functional properties of wheat dough. Cereal Chem 76:389-394.

Yagdi K, Sozen E. 2009. Heritability, variance components and correlations of yield and quality traits in durum wheat (Triticum durum Desf.). Pak. J. Bot., 41(2): 753-759.

Yetsedaw Aynewa, Tadesse Dessalegn and Wondimu Bayu. 2013. Participatory evaluation of malt barley (Hordeum vulgare L.) genotypes for yield and other agronomic traits at North-West Ethiopia. Wudpecker Journal of Agricultural Research, Vol. 2(8), pp. 218 - 222. 